\title{
Influence of Nerve Growth Factor on Neurofilament Gene Expression in Mature Primary Sensory Neurons
}

\author{
V. M. K. Verge, ${ }^{1}$ W. Tetzlaff, ${ }^{2}$ M. A. Bisby, ${ }^{3}$ and P. M. Richardson ${ }^{1}$ \\ 'Division of Neurosurgery, Montreal General Hospital and McGill University, Montreal, Quebec, Canada H3A 2T5, \\ 'Departments of Anatomy and Pathology, University of Calgary, Calgary, Alberta, Canada T2N 1N4, and ${ }^{3}$ Department of \\ Physiology, Queen's University, Kingston, Ontario, Canada K7L 3N6
}

To analyze the possible influence of nerve growth factor (NGF) on neurofilament synthesis in primary sensory neurons, adjacent cryostat sections of lumbar dorsal root ganglia (DRG) from adult rats were processed for either NGF. receptor radioautography or in situ hybridization with a neurofilament cDNA probe. Labeling by both procedures was quantified with computer assistance for approximately 300 neurons in each of selected ganglia. For uninjured neurons, no correlation was detected between NGF binding and neurofilament mRNA, even after infusion of NGF into the lumbar subarachnoid space for 1 week. One or 3 weeks after sciatic nerve transection, neurofilament labeling densities in large DRG neurons were sharply reduced and the normal bimodal pattern in frequency histograms had become unimodal. Intrathecal infusion of NGF counteracted this injury-induced reduction of neurofilament mRNA but only in neurons with high-affinity NGF receptors. To explain the effects of NGF on axotomized neurons and the normal diversity of neurofilament gene expression among neurons with NGF receptors, we postulate that NGF permits NGF-sensitive DRG neurons to respond differentially to a second factor stimulating neurofilament synthesis.

The number of neurofilaments within axons is believed to control their diameter and thereby their conduction velocity: neurofilament number and axonal diameter are closely correlated with each other under normal and abnormal conditions (Fricdc and Samorajski, 1970; Weiss and Mayr, 1971; Hoffman et al., 1984). Given an additional correlation between conduction velocity and size of the nerve cell body (Harper and Lawson, 1985; Lee et al., 1986), it is appropriate that large neurons have more neurofilaments than small neurons (Sharp et al., 1982). From analyses of perikaryal size, cytoplasmic appearance, and neurofilament immunohistochemistry, rodent primary sensory neurons have been subdivided into small dark neurons with unmyelinated axons and large light neurons with myelinated axons (Andres, 1971; Duce and Keen, 1977; Lawson, 1979; Rambourg et al., 1983; Lawson et al., 1984). The tinctorial properties of

\footnotetext{
Received Nov. 17, 1989; revised Jan. 15, 1990; accepted Jan. 31, 1990.

We thank J.-P. Julien for the neurofilament cDNA clone and W. G. Tatton for the image-analysis software. This work was supported by grants from the Medical Research Council of Canada, the National Institutes of Health (ISSA), and the Rick Hansen Man in Motion Legacy Fund. Valerie Verge received a studentship from the Canadian Paraplegic Association.

Correspondence should be addressed to Dr. Peter Richardson, Montreal General Hospital, 1650 Cedar Avenue, Montreal, Quebec, Canada H3G 1 A4.

Copyright (C) 1990 Society for Neuroscience $0270-6474 / 90 / 062018-08 \$ 02.00 / 0$
}

large light neurons are probably related to the presence of many perikaryal neurofilaments. It is intriguing to speculate that a few molecules influencing expression of the neurofilament gene might control such fundamental properties as neuronal size and conduction velocity. However, nothing is yet known about the molecules that regulate neurofilament content of dorsal root ganglion (DRG) neurons.

Nerve growth factor (NGF) increases expression of the genes for all 3 neurofilament subunits in cloned pheochromocytoma (PC-12) cells (Dickson et al., 1986; Lindenbaum et al., 1988). The hypertrophy of primary sensory neurons following NGF injection into chick embryos (Straznicky and Rush, 1985; Dimberg et al., 1987) may reflect induction of neurofilament synthesis by NGF. The fact that axons of adult rat sensory neurons undergo atrophy following administration of NGF antiserum suggests a regulatory role for endogenous NGF in axonal caliber (Matheson et al., 1989). In mature rats, approximately $40 \%$ of lumbar sensory neurons have high-affinity NGF rcceptors and are potentially responsive to NGF (Verge et al., 1989a, b). We were therefore interested in determining whether endogenous NGF is involved in controlling neurofilament synthesis in normal mature DRG neurons.

Several properties of NGF-sensitive sensory neurons, notably the concentration of substance $P$, are maintained by endogenous NGF (Lindsay and Harmar, 1989), falling when NGF is depleted by antibodies (Schwartz et al., 1982) or injury (Jessell et al., 1979) and augmented by infusion of exogenous NGF (Goedert et al., 1981; Fitzgerald et al., 1985). Following peripheral nerve transection, nerve cell body size, axonal diameter, neurofilament synthesis, and axonal transport of neurofilament are all reduced in sensory neurons (Cavanaugh, 1951; Aitken and Thomas, 1962; Carlson et al., 1979; Hoffman et al., 1987; Wong and Oblinger, 1987; Goldstein et al., 1988; Oblinger and Lasek, 1988). NGF can partially prevent or restore this injury-induced atrophy (Rich et al., 1987; Verge et al., 1989a). We hypothesized that the downregulation of neurofilament synthesis in axotomized sensory neurons with functional NGF receptors might also be counteracted by infusion of NGF.

\section{Materials and Methods}

Operations were performed on 18 female Sprague-Dawley rats, weighing approximately $200 \mathrm{gm}$, with general anesthesia (pentobarbitol, $50 \mathrm{mg}$ / $\mathrm{kg}$, i.p.) and aseptic microsurgical conditions. The right sciatic nerve was transected at its origin from the $\mathrm{L}_{4}$ and $\mathrm{L}_{5}$ spinal nerves and a 5 $\mathrm{mm}$ segment of nerve was excised. In 9 rats, $\beta$-NGF was infused at 1 $\mu \mathrm{l} / \mathrm{hr}$ by a subcutaneous osmotic pump (Alza $\# 2001$ ) connected to silicon tubing (outer diameter, $0.6 \mathrm{~mm}$ ) inserted intrathecally at the lumbosacral junction to a length of $2 \mathrm{~cm}$. $\beta-N G F$, prepared from mouse sub- 


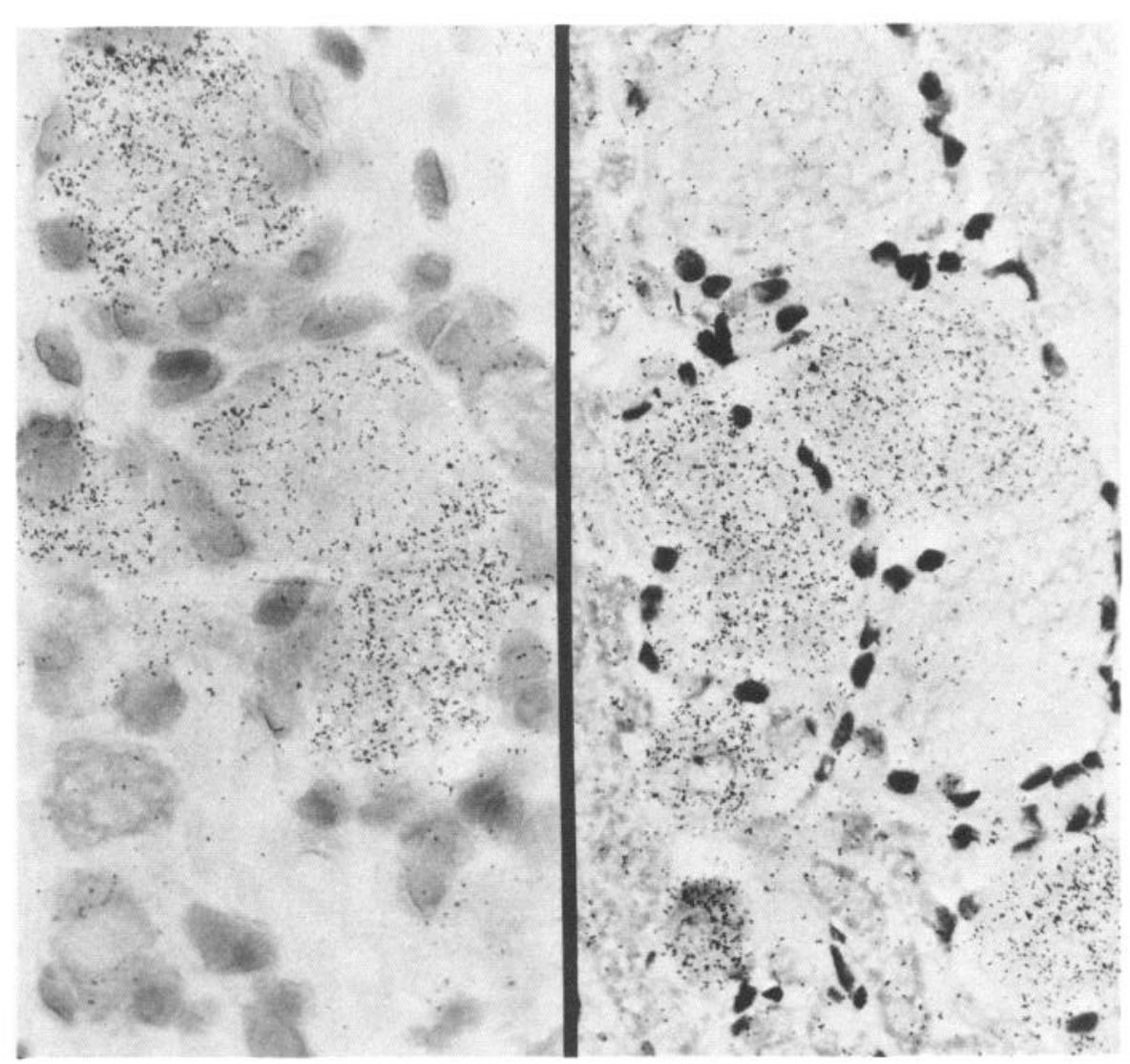

Figure 1. Photomicrographs showing adjacent sections of normal rat $L_{\varsigma}$ DRG processed for in situ hybridization with an NFM cDNA probe (left) or NGF-receptor radioautography (right). NFM mRNA labeling is denser for large than small neurons but shows little relationship to NGF binding. $\times 530$. mandibular glands (Mobley et al., 1976; Chapman et al., 1981), was diluted to $125 \mathrm{ng} / \mu \mathrm{l}$ in PBS containing rat serum albumin $(1 \mathrm{mg} / \mathrm{ml})$, penicillin, and streptomycin (100 units/ml). Four experimental groups were studied with simple nerve transection 1 or 3 weeks before death, and with transection 1 or 4 weeks before death plus infusion of NGF in the last week. At death, rats were deeply anesthetized and perfused per aorta with buffered saline. The fourth and fifth lumbar dorsal root ganglia ( $\mathrm{L}_{4}$ and $\mathrm{L}_{5} \mathrm{DRG}$ ) were removed, and the right and left ganglia at each level were quickly mounted on the same cork and frozen in isopentane cooled to $-60^{\circ} \mathrm{C}$. Cryostat sections $5 \mu \mathrm{m}$ thick were thawmounted on gelatin-coated slides and stored at $-80^{\circ} \mathrm{C}$ for not more than a week. Adjacent sections, each with a pair of DRG, were processed either for NGF-receptor radioautography or neurofilament in situ hybridization.

NGF-receptor radioautography was performed according to a published protocol (Richardson et al., 1989; Verge et al., 1989a). $\beta$-NGF was radioiodinated by the lactoperoxidase method (Sutter et al., 1979 Richardson et al., 1989) to a specific activity of approximately $100 \mu \mathrm{Ci} /$ $\mu \mathrm{g}$. Slides were incubated for $90 \mathrm{~min}$ in $40-50$ pM ${ }^{125} \mathrm{I}-\mathrm{NGF}$ in PBS containing cytochrome $\mathrm{c}(1 \mathrm{mg} / \mathrm{ml})$ to diminish nonspecific labeling and protease inhibitors ( $4 \mu \mathrm{g} / \mathrm{ml}$ leupeptin and $0.5 \mathrm{~mm}$ PMSF). Slides were washed for $3 \mathrm{~min}$ in several changes of cold buffer, fixed in mixed aldehydes, dehydrated, defatted, rehydrated, and dried. They were then dipped in radiosensitive emulsion (Kodak NTB2), exposed in the dark for 4-7 d, and developed (Kodak D-19).

The ${ }^{35} \mathrm{~S}$-radiolabeled probe used for hybridization was generated from isolated cDNA insert of the medium neurofilament subunit (NFM; Julien et al., 1986), according to the random hexonucleotide priming procedure (Feinberg and Vogelstein, 1983). The cDNA clone was generously provided by Dr. J-P. Julien, McGill University. The technique for in situ hybridization was essentially that of Miller et al. (1987). Sections were postfixed for $20 \mathrm{~min}$ in $4 \%$ formaldehyde, washed in buffered saline, treated for $8 \mathrm{~min}$ with proteinase $\mathrm{K}(10 \mathrm{ng} / \mathrm{ml})$ at room temperature, rinsed, and fixed an additional $5 \mathrm{~min}$ in $4 \%$ paraformaldehyde. Sections were then dehydrated in 70,90 , and $100 \%$ ethanol containing $0.3 \mathrm{M}$ sodium acetate, briefly dried, and prehybridized for $2-3 \mathrm{hr}$ at $43^{\circ} \mathrm{C}$ with a solution containing $50 \%$ formamide, $5 \times$ Den- hardt's solution, salmon sperm DNA and tRNA ( $250 \mu \mathrm{g} / \mathrm{ml}), 0.2 \%$ SDS, and $100 \mathrm{~mm}$ DTT. The same solution was used for overnight (12-14 hr) hybridization at $43^{\circ} \mathrm{C}$ with the addition of ${ }^{35} S$-labeled NFM cDNA probe $\left(2 \times 10^{6} \mathrm{cpm} / \mathrm{ml}, 10-20 \mathrm{ng} / \mathrm{ml}\right)$. Posthybridization washes were done at $45^{\circ} \mathrm{C}$ with $4 \times, 2 \times, 1 \times$, and $0.5 \times$ for 30 min each and $0.1 \times$ SSC for $5 \mathrm{~min}$. Sections were processed for radioautography by dipping in Kodak NTB2 emulsion diluted 1:1 in distilled water, exposed in the dark at $4^{\circ} \mathrm{C}$ for $6-14 \mathrm{~d}$, developed in D-19 solution, and stained with toluidine blue. Control sections were hybridized with ${ }^{35} \mathrm{~S}$-labeled plasmid DNA instead of neurofilament cDNA.

Quantitative analysis was performed for 10 ganglia in 5 animals subjected to right sciatic nerve transection with or without NGF infusion. For this purpose, montages were prepared from photomicrographs (at $\times 450$ ) of adjacent sections processed for NGF-receptor radioautography and NFM cDNA hybridization. Neurons with visible nucleolus in 1 of the 2 sections were identifie and numbered on both montages and analyzed quantitatively under oil-immersion light microscopy with computer assistance ( $n=224-360 /$ preparation). Image-analysis software was kindly provided by Dr. W. G. Tatton, University of Toronto. For individual neurons, the cross-sectional area and percentage of cytoplasmic area covered by silver grains were measured in both histological preparations. Volumes were calculated from the larger of the 2 cross-sectional areas in adjacent sections with correction for shrinkage and assumption that the neurons are spherical. Labeling indices included a correction for grain overlap and were normalized against background labeling over areas of the ganglia without nerve cell bodies. Data were analyzed statistically according to published computer programs (Press et al., 1988). Where appropriate, histograms were fitted to a doubleGaussian curve by the Levenberg-Marquardt algorithm.

\section{Results}

\section{Normal ganglia}

In left $\mathrm{L}_{5}$ DRG with or without NGF infusion, labeling of DRG neurons with the NFM cDNA probe was heterogeneous (Fig. 1). Background labeling was $0.0015-0.0024$ of area, and neu- 


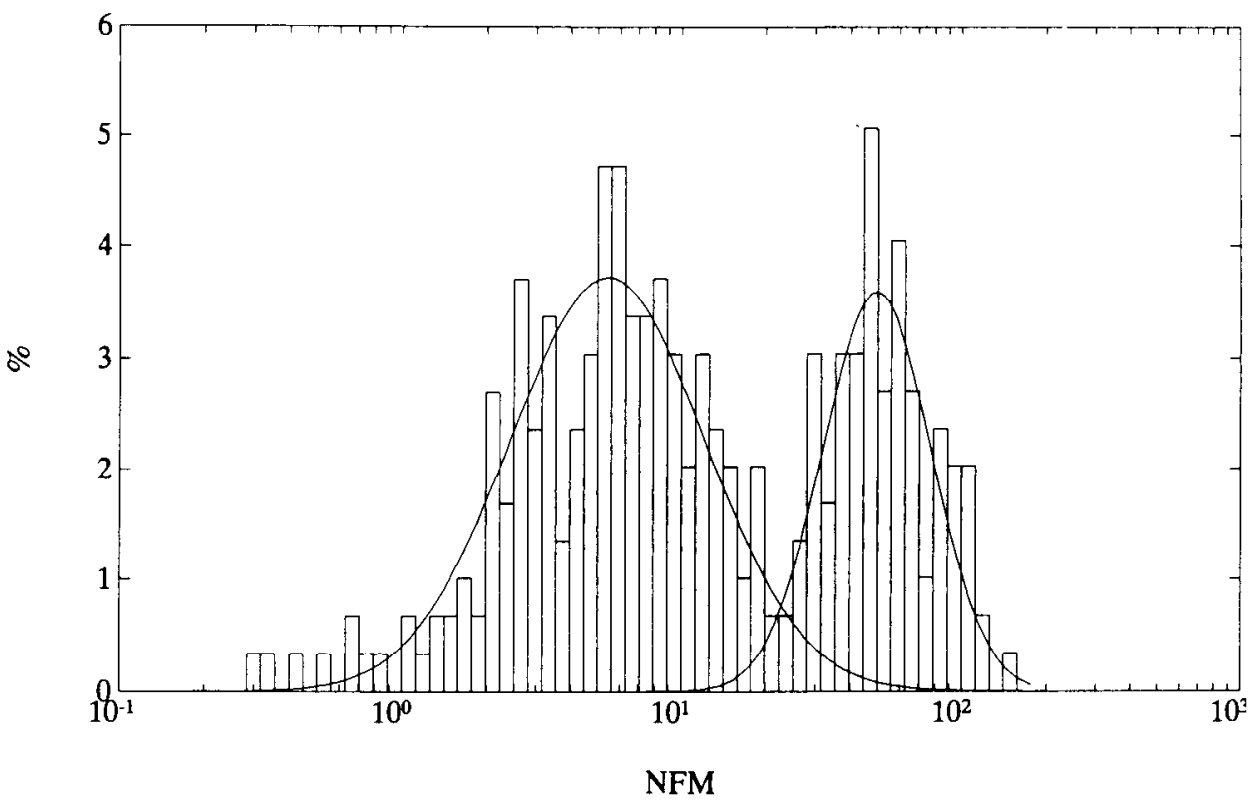

Figure 2. Quantification of NFM $m R N A$ labeling in an uninjured $L_{5} D R G$ of a rat infused intrathecally for 1 week with NGF $(n=296)$. Top, Frequency histogram showing percentage of neurons versus NFM mRNA labeling indices. The data can be fitted to 2 normal curves with mean labeling of $5.4 \times$ background and $50 \times$ background. Middle, Three-dimensional histogram with frequency plotted against neurofilament labeling and volume. The neurons are distributed into 2 major pools with small volume and little NFM mRNA or large volume and abundant mRNA. Volume, 6000-180,000 $\mu \mathrm{m}^{3}$; NFM mRNA labeling index, $0.6-180 \times$ background, both on logarithmic scale. Bottom, Three-dimensional histogram with frequency plotted against NFM mRNA labeling and NGF binding. Little correlation is seen between the 2 labeling indices. NGF labeling index, $0.32-32 \times$ background; NFM labeling index, 0.6-180 $\times$ background, both on logarithmic scale.
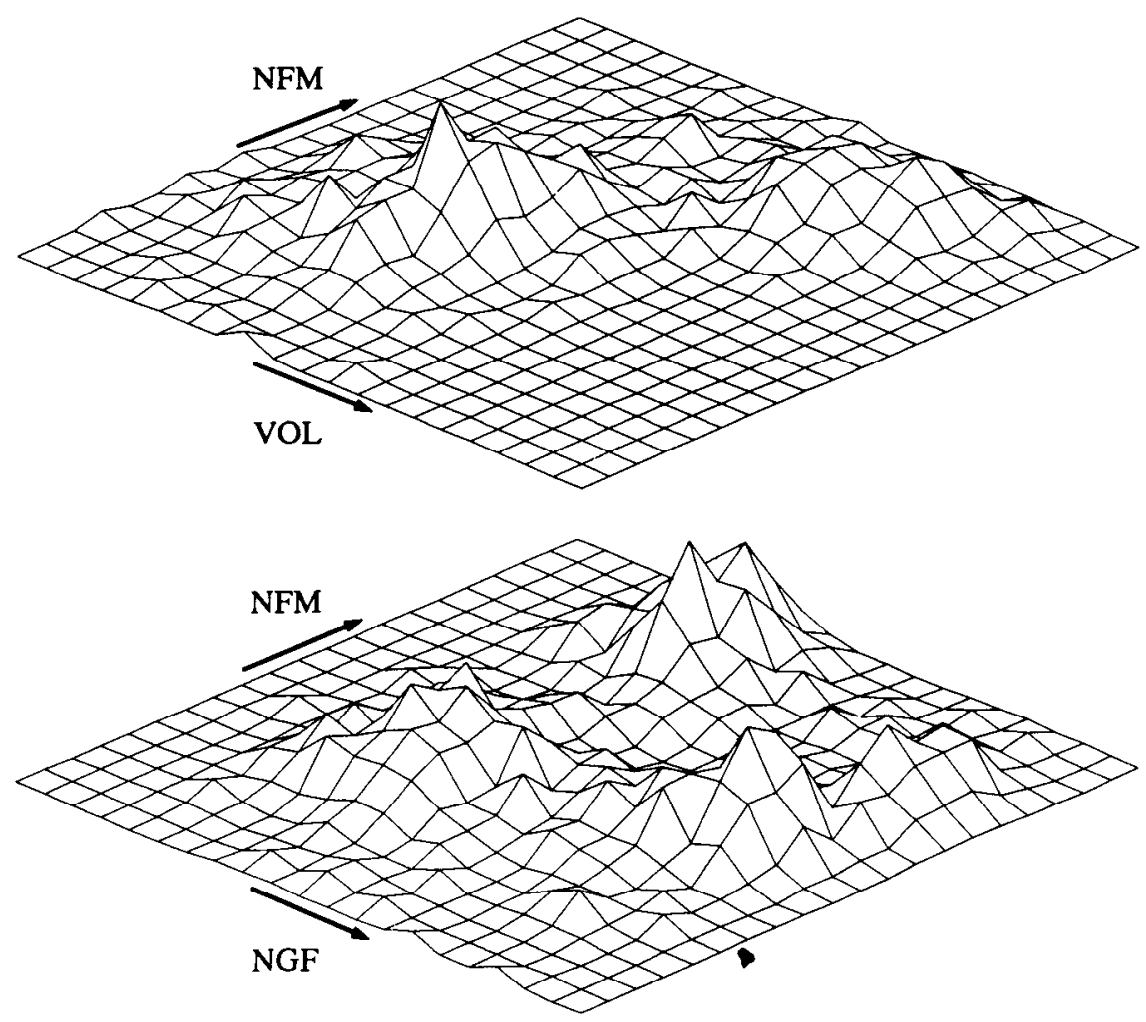

ronal labeling indices ranged from below background to more than 100 times background. Frequency histograms of labeling indices (Fig. 2) could be fitted to 2 normal curves with $0.62 \pm$ 0.04 and $0.38 \pm 0.04$ of neurons and mean labeling indices of $3.4 \pm 0.6$ and $34.9 \pm 4.7$ (logarithmic scale, mean \pm SEM, 5 plots, $250-346$ neurons/plot). No specific labeling was observed for sections hybridized with radiolabeled plasmid.

Frequency histograms of cell volume could also be fitted to 2 normal curves with $0.67 \pm 0.04$ and $0.33 \pm 0.04$ of neurons and mean volumes of $14,000 \pm 700$ and $50,000 \pm 4000 \mu \mathrm{m}^{3}$ (logarithmic scale, mean \pm SEM, 5 plots, 250-346 ncurons pcr plot, data not shown).
In scatter diagrams or 3-dimensional histograms (Fig. 2) to show the frequency distribution of neurons according to volume and NFM mRNA labeling indices (both on a logarithmic scale), a strong correlation between the 2 measurements was detected (Pearson coefficient $=0.64-0.71, p<0.0001$ by Student's $t$-test for the parameter $z, 5$ plots). Most of the neurons belong to 1 of 2 populations, with small volume and light NFM mRNA labeling or large volume and heavy NFM mRNA labeling.

No correlation was detected between labeling indices in NGFreceptor radioautography and NFM in situ hybridization (Figs. $1,2)$. By this analysis, most neurons could be placed into 4 clusters with light or heavy labeling by the 2 procedures. For 
INTACT

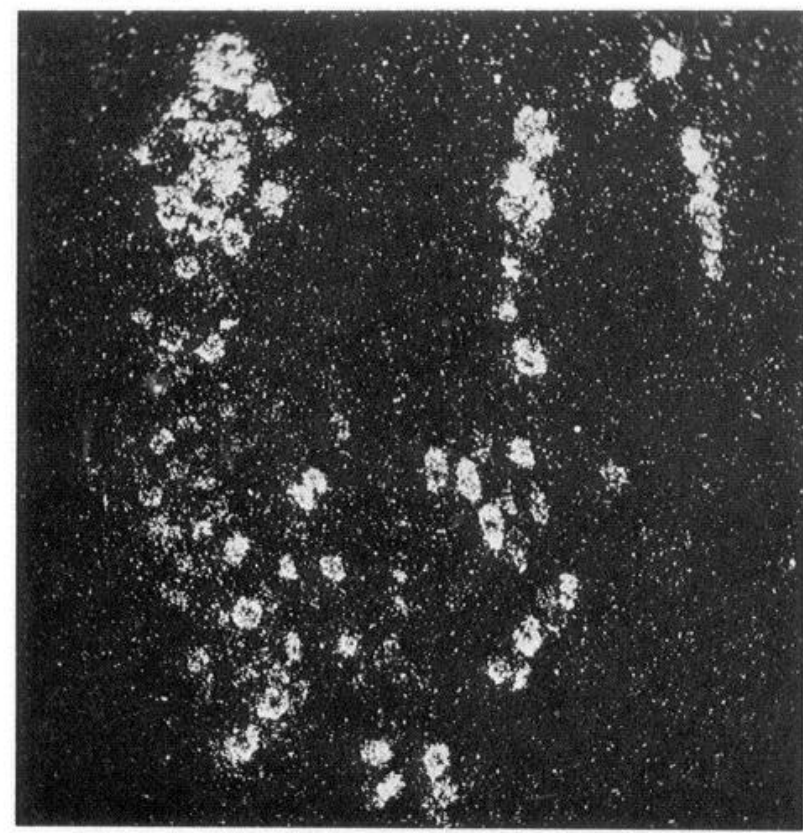

\section{UT}

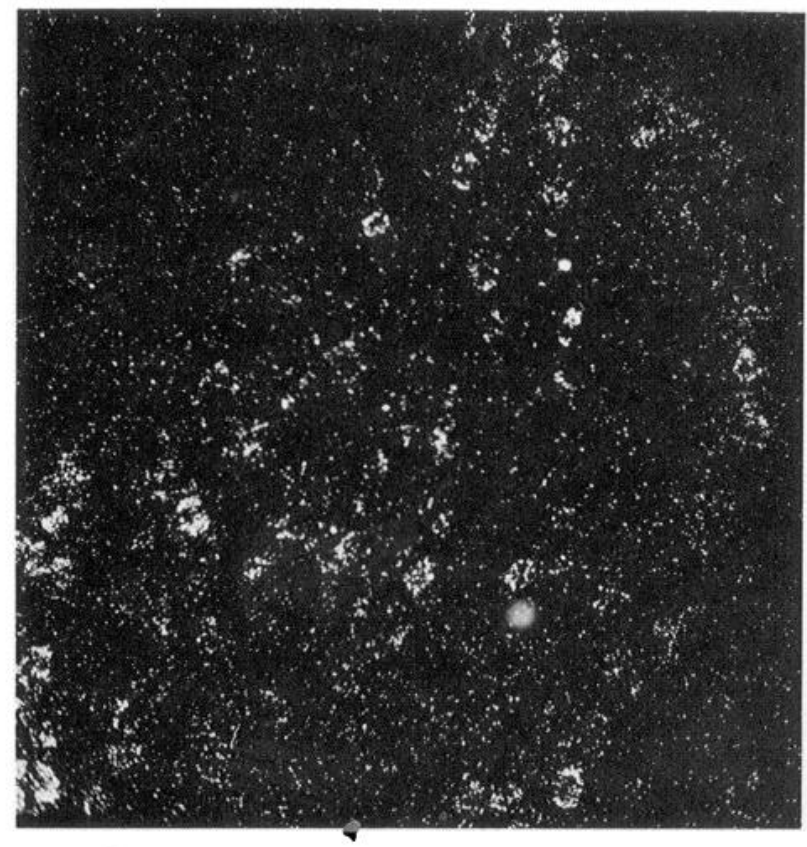

\section{INTACT + NGF}

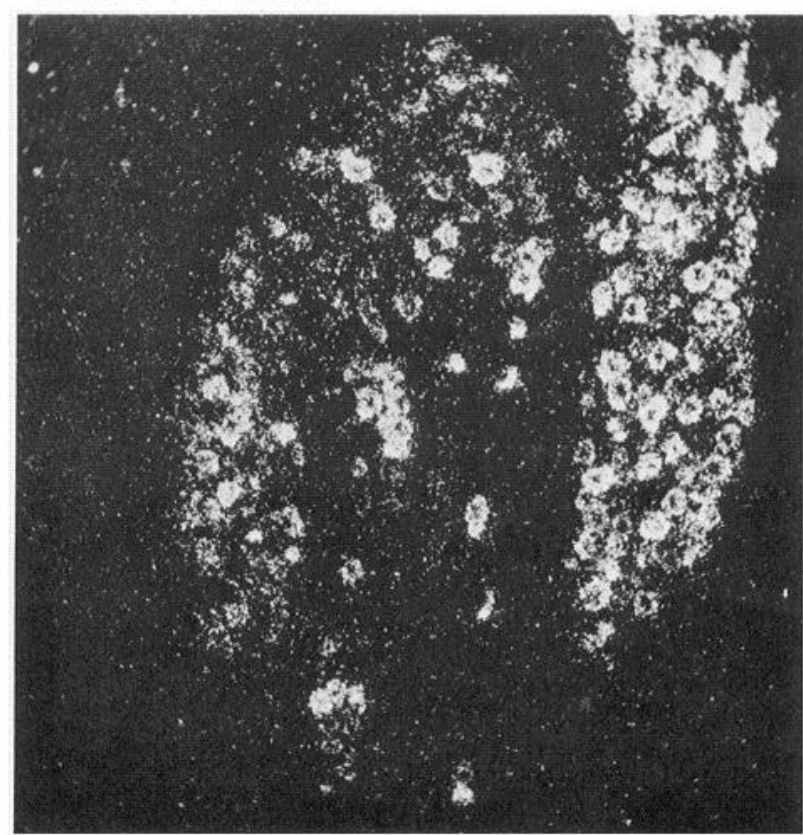

CUT + NG F

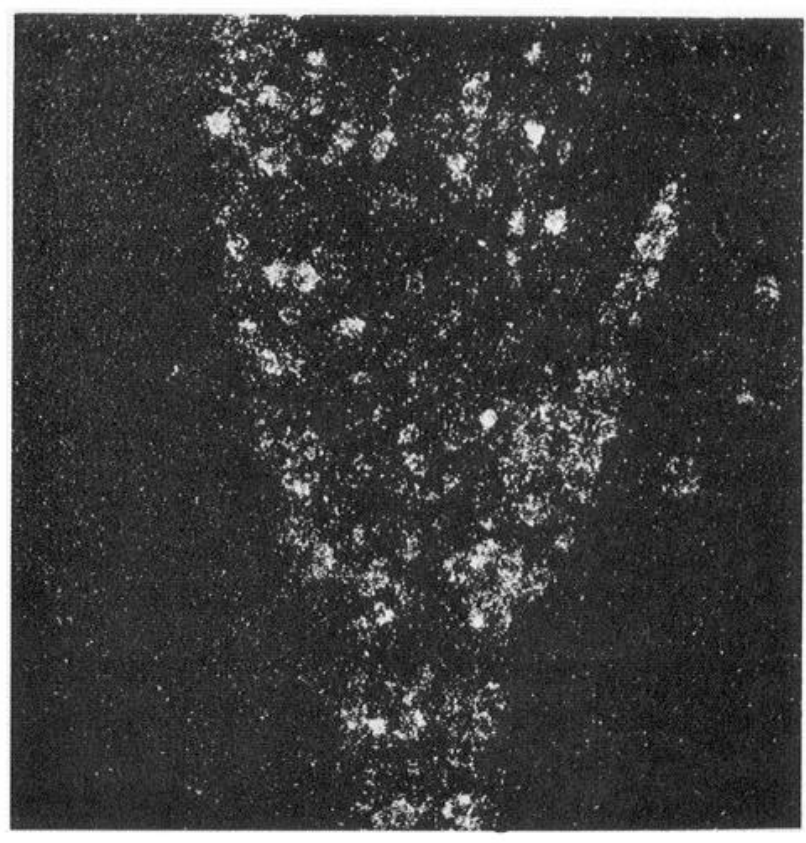

Figure 3. Dark-field photomicrographs showing NFM in situ hybridization for left and right $\mathrm{L}_{\mathrm{s}}$ DRG from 2 rats. In both rats, the right sciatic nerve was cut 1 week before death; for 1 rat, NGF was infused intrathecally during this week. $\mathrm{L}_{5}$ DRGs are associated with normal sciatic nerve (upper), cut sciatic nerve (lower), and NGF infusion (right) or no infusion (left). NFM mRNA is depleted by peripheral nerve injury, but more heavily labeled neurons persist when injury is followed by NGF infusion. $\times 60$.

neurons with little NGF binding, the subpopulations with high and low NFM mRNA concentration were distinct: for neurons with high NGF binding, the 2 populations were less clearly separated, and the total range of NFM mRNA labeling was diminished.

Administration of NGF seemed to accentuate the difference between neuronal populations that were heavily and lightly labeled by the NFM probe (Fig. 3), although this impression was not quantitatively documented. In otherwise normal ganglia, the percentage of neurons in the 2 populations was not appreciably changed by exogenous NGF, and the values quoted in the first paragraph are for left DRG with or without NGF infusion. After administration of NGF, the correlation between NFM mRNA labeling index and neuronal volume was still strong and the four populations of neurons with low or high NGF binding and low or high NFM mRNA labeling were more evident (Figs. 4, 5).

\section{Changes after injury}

As expected from previous reports (Hoffman et al., 1987; Wong and Oblinger, 1987; Goldstein et al., 1988; Verge et al., 1989a), both cytoplasmic NFM mRNA and NGF binding in DRG neu- 
INTAC T

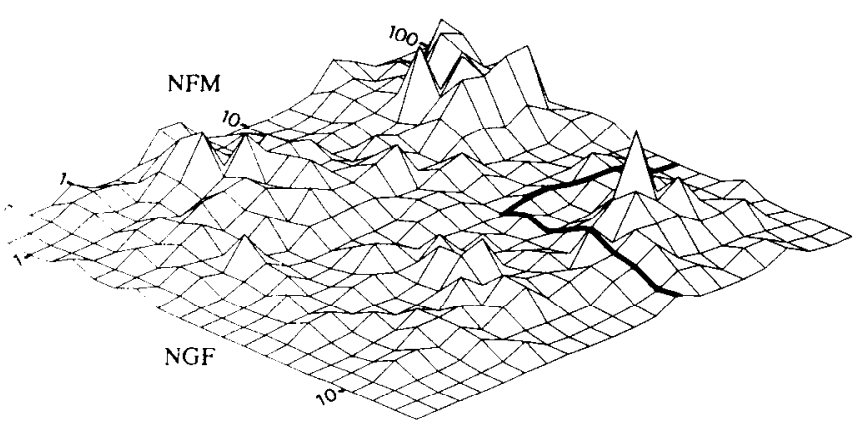

CUT

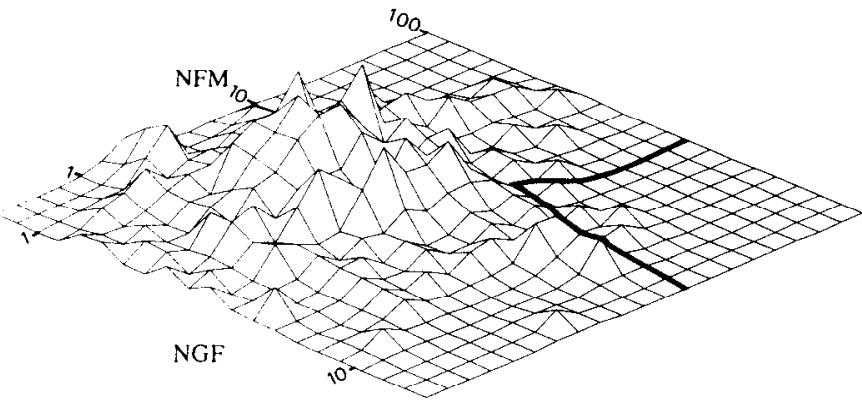

INTACT + NGF

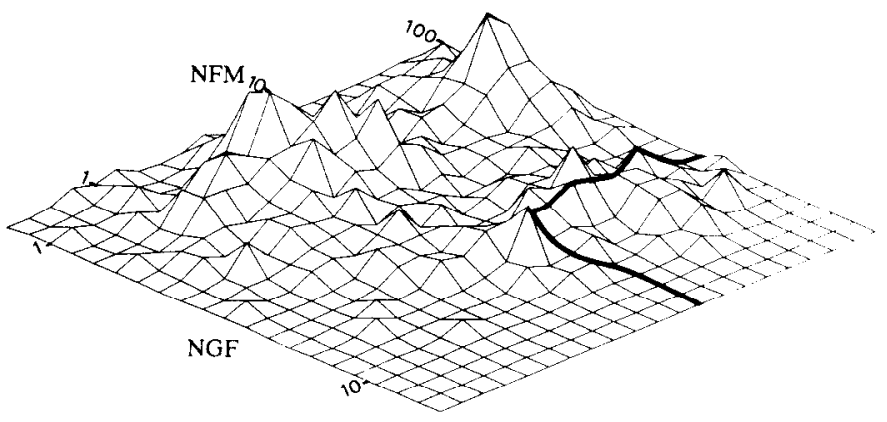

CUT + NGF

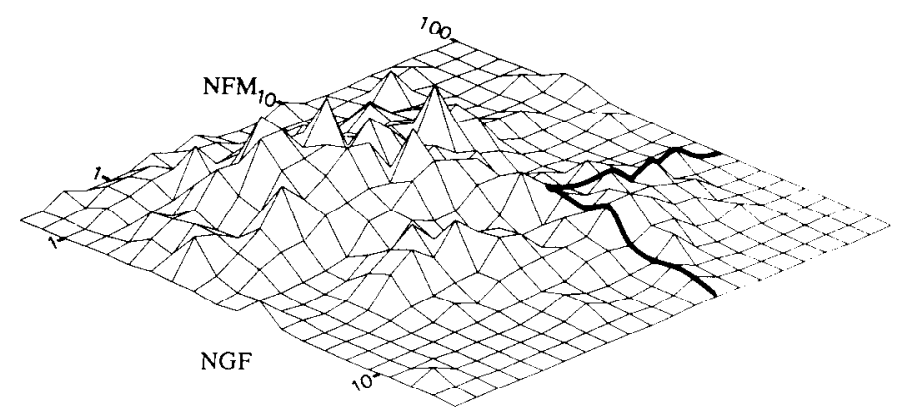

Figure 4. Three-dimensional histograms with neuronal frequency plotted against NFM and NGF labeling indices. Sciatic nerve transection and/ or initiation of NGF infusion were 1 week before death. Normal nerve, no NGF infusion (upper left), cut nerve, no NGF infusion (lower left), normal nerve, NGF infusion (upper right), cut nerve, NGF infusion (lower right). With normal sciatic nerve, NGF and NFM labeling indices are not correlated with each other. Onc weck after sciatic ncrve transection, NFM mRNA is low in all neurons, but NGF binding has changed little from normal. Injury-induced loss of NFM mRNA is prevented by NGF infusion but only for neurons with high NGF binding. The region of each histogram outlined with dark lines arbitrarily designates neurons considered to be very heavily labeled by both procedures. NGF labeling, 0.6$18 \times$ background; NFM labeling, $0.3-100 \times$ background, both on logarithmic scale $(n=231-360)$.

rons fell substantially after sciatic nerve transection. Diminished NFM mRNA labeling in the right as compared to left DRG was apparent upon dark-field inspection of all 9 pairs of ganglia removed 1 or 3 weeks after simple sciatic nerve transection (Fig. 3). The right : left ratio of mean labeling indices for NFM mRNA was 0.29 at 1 week and 0.21 at 3 weeks (quantification for 3 rats, 224-352 neurons). The loss of total cytoplasmic NFM mRNA was even greater because neuronal volume also fell after nerve injury (to 0.91 of normal at 1 week and 0.65 of normal at 3 weeks). In frequency histograms of NFM mRNA labeling indices, the normal bimodal pattern disappeared, and the data fitted reasonably well to a single normal curve (data not shown). Three weeks after nerve transection, both NFM mRNA labeling and NGF binding had unimodal distributions, so that in 3-dimensional plots of frequency versus NGF and neurofilament labeling (Fig. 5), most neurons belonged to a rather homogeneous population with subnormal labeling on both axes.

On dark-field inspection of NFM cDNA hybridizations to DRG, the loss of labeling after sciatic nerve transection was mitigated in 6 of 9 rats infused with NGF (Fig. 3). This visual result was similar irrespective of whether NGF was infused from 0-1 weeks or from 3-4 weeks after nerve injury. In one of the 3 nonresponding rats that was killed 4 weeks after nerve transection, NGF infusion must have been technically unsatisfactory because NGF binding was not restored. Why neurofilament mRNA did not respond to NGF in 2 other animals is unknown because they were killed at 1 week when NGF binding had not fallen enough to be used for monitoring pump adequacy. That NGF counteracts NFM mRNA loss after nerve injury was best substantiated by pattern shifts in 3-dimensional histograms of frequency versus NGF binding and NFM mRNA labeling indices. Infusion of NGF restored NFM mRNA labeling (Fig. 5) or prevented its loss (Fig. 4) in approximately one-half of neurons with high NGF binding but did not significantly alter the changes in neurons with low NGF binding. For the one-third of neurons most heavily labeled by NGF (Fig. 6), the right : left ratio of mean NFM mRNA labeling indices fell to 0.27 at 3 weeks after right sciatic nerve transection and was restored to 0.83 after a further week of NGF infusion (quantification for 2 rats, 224-297 neurons).

\section{Discussion}

\section{Technical considerations}

The dual quantification of NGF binding and NFM mRNA labeling for hundreds of neurons permits correlations and conclusions that are not evident on visual inspection, independent consideration of parameters or global analysis of the DRG. Sideto-side comparisons of absolute values between ganglia of the same animal seem valid when each of the pair is mounted on the same slide and treated by identical histological procedures. Because of presumed variability in the conditions for in situ hybridization, no conclusions have been based on comparison of mean labeling indices between sections mounted on different 


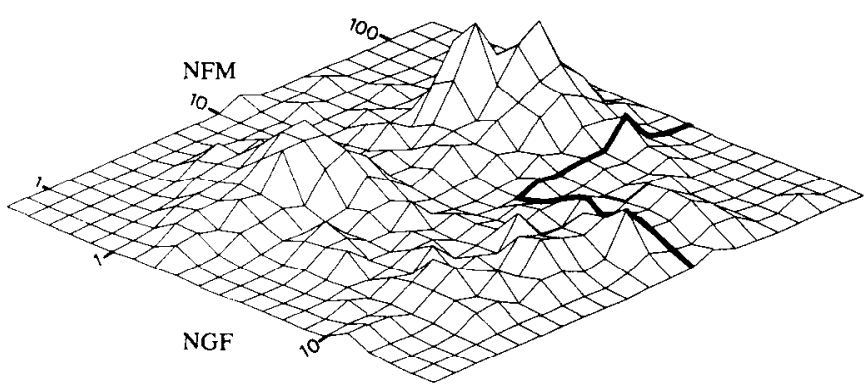

CUT

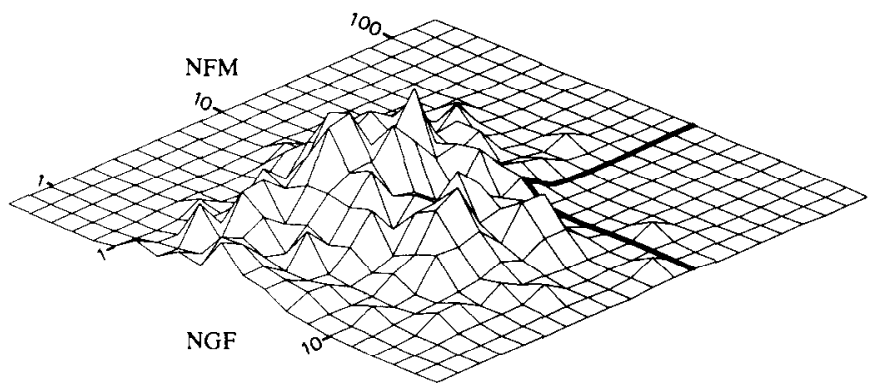

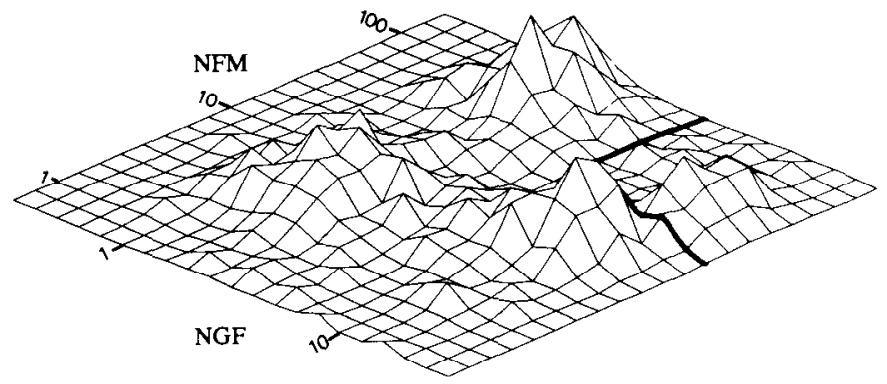

$\mathrm{CUT}+\mathrm{NGF}$

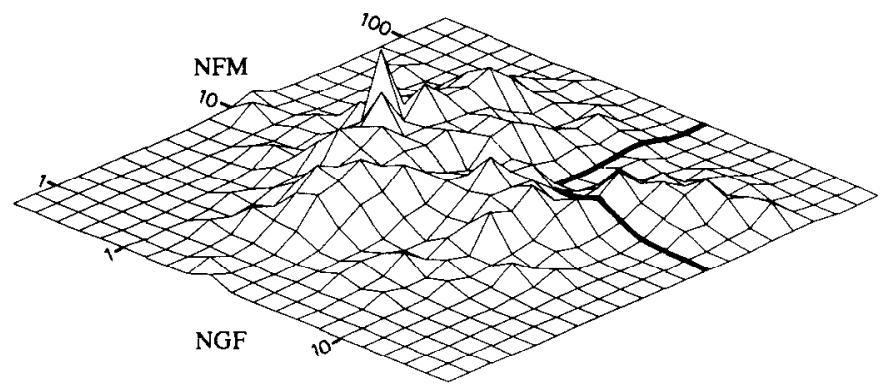

Figure 5. Three-dimensional histograms with neuronal frequency plotted against NFM mRNA and NGF labeling indices to show the effects of delayed infusion of NGF. Normal nerve, no NGF infusion (upper left); nerve cut 3 weeks before death, no NGF infusion (lower left); normal nerve, NGF infusion for 1 week (upper right); nerve cut 4 weeks before death, NGF infusion for last week (lower right). With normal sciatic nerve, neurons can be placed into 4 subpopulations with high or low labeling by both procedures. Three weeks after simple sciatic nerve transection, NGF binding and NFM mRNA are reduced for neurons with or without high-affinity NGF receptors. NFM mRNA is restored by delayed infusion of NGF for some neurons with high NGF binding and therefore high-affinity NGF receptors. However, NGF does not counteract the loss of NFM mRNA in the subpopulation that normally lacks NGF receptors yet has abundant neurofilament mRNA. Again, the outlined regions contain neurons heavily labeled by both markers. NGF labeling, $0.32-32 \times$ background; neurofilament labeling, $0.6-180 \times$ background, both on logarithmic scale $(n=224-$ 297).

slides. However, consistent changes in patterns of 3-dimensional frequency histograms seem to be a reliable indication of real change, not attributable to variability in hybridization conditions.

The present data concern only the medium neurofilament subunit, yielding no direct information about the light and heavy subunits.

\section{Classification of sensory neurons}

Among normal rat DRG neurons, the frequency distributions of NFM mRNA concentration and volume are bimodal and strongly correlated with each other. These observations support the concept of a fundamental division between small dark and large light neurons, NFM mRNA serving as a marker for the latter population. NFM mRNA is not absent in small sensory neurons, merely scarce. The data are entirely consistent with the suggestion that neurofilament content is an important determinant of neuronal size and axonal diameter. It also appears that the difference in neurofilament content between the 2 populations of neurons is determined by different rates of neurofilament synthesis rather than other possible explanations.

In normal DRG, NFM mRNA concentration was not correlated with NGF binding. Neurons with or without high-affinity NGF receptors could be large or small and could have high or low concentration of NFM mRNA. It can therefore be assumed that some NGF-receptor bearing sensory neurons have unmyelinated axons and some have myelinated axons (Harper and Lawson, 1985; Lee et al., 1986). This result stands in contrast to studies correlating NGF binding with neuropeptides where close colocalization or absence of colocalization was the rule (Verge et al., 1989b). It can be concluded that small dark and large light neurons in rat DRG are not homologous to small dorsomedial NGF-responsive and large ventrolateral NGF-unresponsive neurons in chick DRG (Raivich et al., 1987). The unknown factors governing expression of the genes for the NGF receptor and neurofilament seem to be largely independent of one another.

\section{Regulation of the neuroflament gene}

This and other studies (Hoffman et al., 1987; Wong and Oblinger, 1987; Goldstein et al., 1988; Tetzlafr et al., 1988) show that neurofilament protein and mRNA have fallen markedly in neurons 1 week after their peripheral axons have been cut. The reduction in NFM $m$ RNA is followed by reduction in perikaryal volume, more evident at 3 weeks than 1 week. The axotomyinduced change in NFM mRNA is obvious in large light neurons that normally synthesize neurofilament abundantly. We cannot say with confidence whether NFM synthesis is also reduced in small neurons that normally have little NFM mRNA. Why neurofilament mRNA falls after axonal injury has not been 

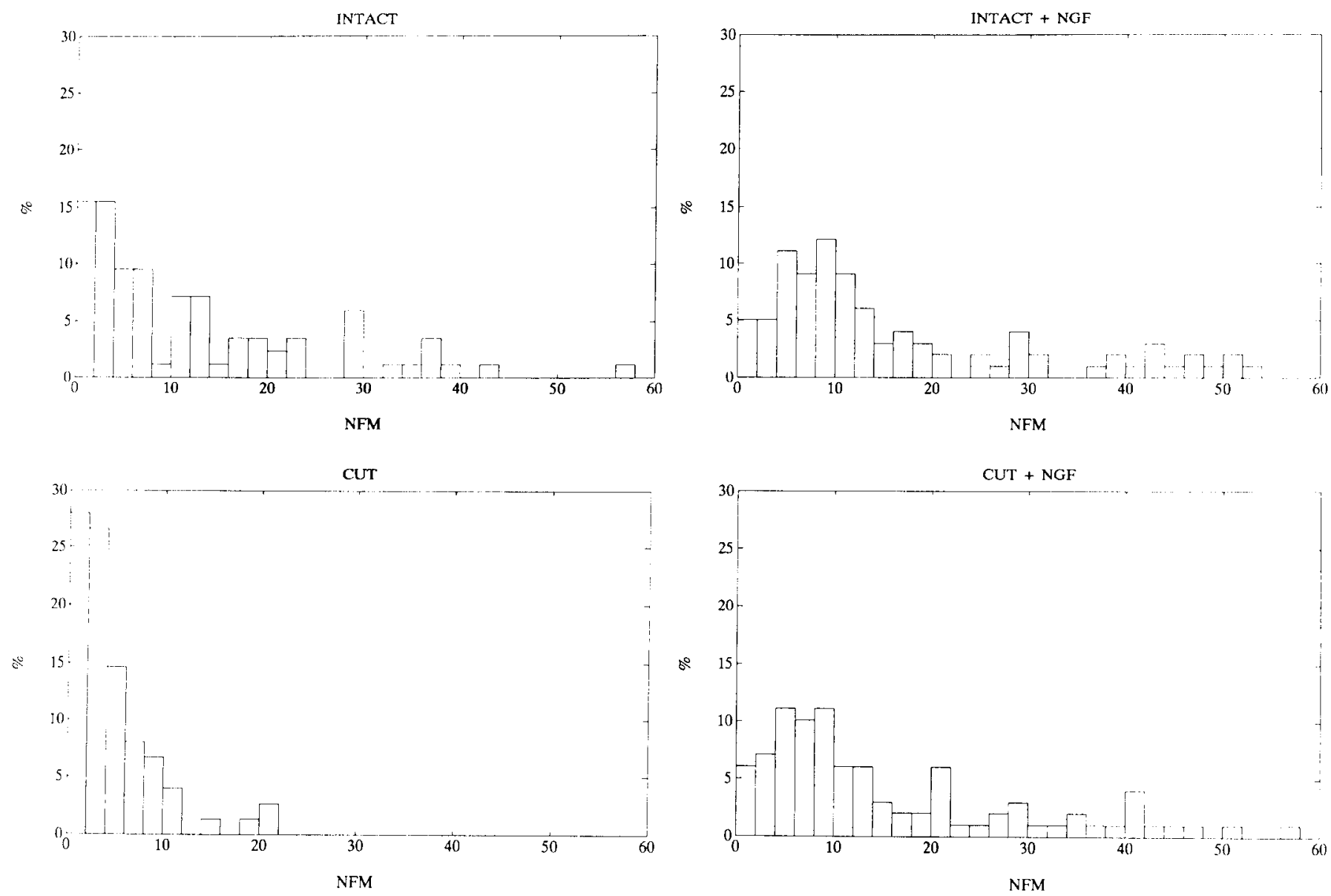

Figure 6. Frequency histograms of NFM labeling indices ( $\times$ background) for the one-third of neurons in Figure 5 with densest binding of NGF Intact NGF-receptor-positive neurons are heterogenous in their content of NFM mRNA (upper panel). Three weeks following injury few of such neurons have more than 10 times background labeling for NFM mRNA (lower left). A population of neurons rich in NFM mRNA reappears following delayed infusion of NGF (lower right) $(n=75-99)$.

rigorously established. Probably, reduced retrograde transport of NGF causes the change in neurofilament mRNA in NGFreceptor-bearing neurons, some analogous growth factor being implicated for other neurons. Alternatively, it is possible that loss of a single common factor is responsible for the postinjury reduction of neurofilament $\mathrm{mRNA}$ in both NGF-sensitive and NGF-insensitive neurons, being overcome by exogenous NGF for only that neuronal subpopulation with functional NGF receptors.

In controlling neurofilament gene expression, NGF appears to have more limited influence on sensory neurons in vivo than on clonal cell lines in vitro. For adult rat DRG neurons, sensitivity to NGF is neither necessary nor sufficient for high levels of neurofilament gene expression. Some neurons with high concentrations of NFM mRNA do not bear high-affinity NGF receptors, and some neurons with NGF receptors have low concentrations of NFM mRNA. However, NGF is relevant to NFM synthesis in sensory neurons with NGF receptors because it counteracts postaxotomy down-regulation of NFM mRNA (Figs. 4-6). One speculative explanation of these results is that NGF (or other trophic factors for NGF-insensitive DRG neurons) permits neurons to respond differentially to some unknown factor that stimulates neurofilament synthesis. Axotomy, by depriving cells of retrogradely transported trophic factor(s), abol- ishes the permissive state, reducing expression of the neurofilament gene to a basal level in all DRG neurons. $\Lambda$ pplication of NGF restores the permissive state and a normal range of neurofilament mRNA concentration in NGF-sensitive neurons.

\section{References}

Aitken JT, Thomas PK (1962) Retrograde changes in fiber size following nerve section. J Anat 96:121-129.

Andres KH (1971) Untersuchungen über den Feinbau von Spinalganglien. Z Zellforsch Mikroskop Anat 55:1-48.

Carlson J, Lais AC, Dyck PJ (1979) Axonal atrophy from permanent peripheral axotomy in adult cat. J Neuropathol Exp Neurol 38:579 585.

Cavanaugh MW (1951) Quantitative effects of the peripheral innervation area on nerves and spinal ganglion cells. J Comp Neurol 94: 181-219.

Chapman CA, Banks BEC, Vernon CA, Walker JM (1981) The isolation and characterisation of nerve growth factor from the prostate gland of the guinea-pig. Eur J Biochem 115:347-351.

Dickson G, Prentice H, Julien J-P, Ferrari G, Leon A, Walsh FS (1986) Nerve growth factor activates Thy-1 and neurofilament gene transcription in rat $\mathrm{PC} 12$ cells. EMBO J 5:3449-3453.

Dimberg Y, Hedlund KO, Ebendal T (1987) Effects of nerve growth factor on sensory neurons in the chick embryo: a stereological study. Int J Dev Neurosci 5:207-213.

Duce IR, Keen P (1977) An ultrastructural classification of the neu- 
ronal cell bodies of the rat dorsal root ganglion using zinc iodideosmium impregnation. Cell Tissue Res 185:263-277.

Feinberg AP, Vogelstein B (1983) A technique for radiolabelling DNA restriction endonuclease fragments to high specific activity. Anal Biochem 13:6-13.

Fitzgerald M, Wall PD, Goedert M, Emson PC (1985) Nerve growth factor counteracts the neurophysiological and neurochemical effects of chronic sciatic nerve section. Brain Res 332:131-141.

Friede RL, Samorajski T (1970) Axon caliber related to neurofilaments and microtubules in sciatic nerve fibers of rats and mice. Anat Rec 167:379-387.

Goedert M, Stoeckel K, Otten U (1981) Biological importance of the retrograde axonal transport of nerve growth factor in sensory neurons. Proc Natl Acad Sci USA 78:5895-5898.

Goldstein ME, Weiss SR, Lazzarini RA, Shneidman PS, Lees JF, Schlaepfer WW (1988) mRNA levels of all three neurofilament proteins decline following nerve transection. Mol Brain Res 3:287292.

Harper AA, Lawson SN (1985) Conduction velocity is related to morphological cell type in rat dorsal root ganglion neurones. J Physiol (Lond) 359:31-46.

Hoffman PN, Griffin JW, Price DL (1984) Control of axonal caliber by neurofilament transport. J Cell Biol 99:705-714.

Hoffman PN, Cleveland DW, Griffin JW, Landes PW, Cowan NJ, Price DL (1987) Neurofilament gene expression: a major determinant of axonal caliber. Proc Natl Acad Sci USA 84:3472-3476.

Jessell T, Tsunoo A, Kanazawa I, Otsuka M (1979) Substance P: depletion in the dorsal horn of rat spinal cord after section of the peripheral processes of primary sensory neurons. Brain Res 168:247259.

Julien J-P, Meyer D, Flavell D, Hurst J, Grosveld F (1986) Cloning and developmental expression of the murine neurofilament gene family. Mol Brain Res 1:243-250.

Lawson SN (1979) The postnatal development of large light and small dark neurons in mouse dorsal root ganglia: a statistical analysis of cell numbers and size. J Neurocytol 8:275-294.

Lawson SN, Harper AA, Harper EI, Garson JA, Anderton BH (1984) A monoclonal antibody against neurofilament protein specifically labels a subpopulation of rat sensory neurones. J Comp Neurol 228: 263-272.

Lee KH, Chung K, Chung JM, Coggeshall RE (1986) Correlation of cell body size, axon size, and signal conduction velocity for individually labelled dorsal root ganglion cells in the cat. J Comp Neurol 243:335-346.

Lindenbaum MH, Carbonetto S, Grosveld F, Flavell D, Mushynski WE (1988) Transcriptional and post-transcriptional effects of nerve growth factor on expression of the three neurofilament subunits in PC-12 cells. J Biol Chem 263:5662-5667.

Lindsay RM, Harmar AJ (1989) Nerve growth factor regulates expression of neuropeptide genes in adult sensory neurones. Nature 337: 362-364

Matheson SF, Gold B, Mobley WC (1989) Somatofugal axonal atrophy in intact adult sensory neurons following injection of nerve growth factor (NGF) antiserum. Soc Neurosci Abstr 15:707.
Miller FD, Naus CCG, Durand M, Bloom FE, Milner RJ (1987) Isotypes of $\alpha$-tubulin are differentially regulated during neuronal maturation. J Cell Biol 105:3065-3073.

Mobley WC, Schenker A, Shooter EM (1976) Characterization and isolation of proteolytically modified nerve growth factor. Biochemistry $15: 5543-5551$.

Oblinger MM, Lasek RJ (1988) Axotomy-induced alterations in the synthesis and transport of neurofilaments and microtubules in dorsal root ganglion cells. J Neurosci 8:1747-1758.

Press WH, Flannery BP, Teukolsky SA, Vetterling WT (1988) Numerical recipes in C. Cambridge, UK: Cambridge UP.

Raivich G, Zimmermann A, Sutter A (1987) Nerve growth factor (NGF) receptor expression in chicken cranial development. J Comp Neurol 256:229-245.

Rambourg A, Clermont Y, Beaudet A (1983) Ultrastructural features of six types of neurons in rat dorsal root ganglia. J Neurocytol 12: 47-66.

Rich KM, Luszczynski JR, Osborne PA, Johnson EM Jr (1987) Nerve growth factor protects adult sensory neurons from cell death and atrophy caused by nerve injury. J Neurocytol 16:261-268.

Richardson PM, Vergc VMK, Riopcllc RJ (1989) Quantitative radioautography for NGF receptors. In: Nerve growth factors (Rush RA, ed), pp 315-326. New York: Wiley.

Schwartz JP, Pearson J, Johnson EM (1982) Effect of exposure to antiNGF on sensory neurons of adult rats and guinea pigs. Brain Res 244 : 378-381.

Sharp GA, Shaw G, Weber K (1982) Immunoelectron-microscopical localization of the three neurofilament triplet proteins along neurofilaments of cultured dorsal root ganglion neurones. Exp Cell Res 137: $403-413$.

Straznicky C, Rush R (1985) The effect of nerve growth factor on developing primary sensory neurons of the trigeminal nerve in chick embryos. Anat Embryol 171:91-95.

Sutter A, Riopelle RJ, Harris-Warrick RM, Sutter EM (1979) Nerve growth factor receptors. Characterization of two distinct classes of binding sites on chick embryo sensory ganglia cells. J Biol Chem 254: 5972-5982.

Tetzlaff W, Bisby MA, Kreutzberg GW (1988) Changes in cytoskeletal proteins in the rat facial nucleus following axotomy. J Neurosci 8: 3131-3189.

Verge VMK, Riopelle RJ, Richardson PM (1989a) Nerve growth factor receptors on normal and injured sensory neurons. J Neurosci 9 : 914-922.

Verge VMK, Richardson PM, Benoit R, Riopelle RJ (1989b) Histochemical characterization of sensory neurons with high-affinity receptors for nerve growth factor. J Neurocytol 18:583-591.

Weiss PA, Mayr R (1971) Organelles in neuroplasmic ("axonal") flow: neurofilaments. Proc Natl Acad Sci USA 68:846-850.

Wong J, Oblinger MM (1987) Changes in neurofilament gene expression occur after axotomy of dorsal root ganglion neurons: an in situ hybridization study. Metab Brain Dis 2:291-303. 